\title{
Kemampuan Menulis Kalimat melalui Learning Contracts Method bagi Anak Berkesulitan Belajar Menulis
}

\author{
Miftahur Rizka $^{1}$, Asep Ahmad Sopandi ${ }^{2}$, Ardisal $^{3}$ \\ ${ }^{123}$ Universitas Negeri Padang, Indonesia \\ Email: miftahurrizka12@gmail.com
}

\section{INFORMASI ARTIKEL}

terkirim 26 Januari 2018

Revisi dari 09 April 2018

Diterima 10 Mei 2018

\section{Kata kunci:}

Learning Cotracts Method, Anak

Kesulitan Belajar, Menulis Kalimat

\begin{abstract}
ABSTRAK
Penelitian ini dilatar belakangi oleh permasalahan anak berkesulitan belajar $\mathrm{X}$ yang belum dapat menulis kalimat berpola SPOK yang peneliti temukan di SD N 02 Cupak Tangah. Berdasarkan hal tersebut peneliti bertujuan untuk meningkatkan kemampuan anak berkesulitan belajar X dalam menulis kalimat berpola SPOK melalui learning contracts method. Metode penelitian yang digunakan adalah Single Subject Research (SSR). Penelitian ini menggunakan desain $\mathrm{A}_{1}-\mathrm{B}-\mathrm{A}_{2}$. Hasil Penelitian menunjukan bahwa pada kondisi $\mathrm{A}_{1}$ (baseline) diperoleh data frekuensi kalimat yang dituliskan dengan benar masih rendah, pada kondisi B (intervensi) diperoleh data frekuensi kalimat yang dituliskan dengan benar meningkat dari pada kemampuan awal, dan pada kondisi $\mathrm{A}_{2}$ (baseline) diperoleh data frekuensi kalimat berpola SPOK yang ditulis dengan benar meningkat. Berdasarkan data tersebut, menunjukan bahwa kemampuan kemampuan menulis kalimat berpola SPOK anak berkesulitan belajar X dapat meningkat melalui learning contracts method.
\end{abstract}

\section{Pendahuluan}

Menulis merupakan salah satu pemerolehan ilmu pengetahuan, menulis dapat dikategorikan menulis dengan tangan, mengeja, dan menulis ekspresif. Menulis dengan tangan disebut juga menulis permulaan dan berkaitan erat dengan membaca, sedangkan menulis ekspresif disebut juga mengarang atau komposisi. Kegiatan menulis dapat mengembangkan kemampuan komunikasi lisan maupun tulisan, dalam kehidupan moderen keterampilan menulis ekspresif sangat dibutuhkan. Keterampilan menulis ekspresif membantu seseorang dalam merekam, mencatat, meyakinkan, melaporkan, memberitahukan, serta mempengaruhi orang lain. Menulis adalah proses mengungkapkan gagasan, pikiran dan perasaan dalam bentuk tulisan (Latae, Barasandji \& Mugsin, 2015). Tanpa memiliki kemampuan untuk menulis, siswa akan mengalami banyak kesulitan dalam melaksanakan proses proses pembelajaran (Febriana, 2015).

Menulis ekspresif adalah mengungkapkan pikiran atau perasaan ke dalam suatu bentuk tulisan, sehingga dapat dipahami oleh orang lain yang sebahasa (Latae dkk, 2015). Menulis ekspresif erat kaitanya dengan kemampuan anak menulis kalimat. Menulis kalimat merupakan kegiatan menulis mendasar untuk mendukung kegiatan menulis ekspresif lainya. Kalimat adalah ujaran yang mengungapkan gagasan, perasaan, atau pikiran yang relatif lengkap. Jika disampaikan secara tertulis diawali dengan huruf kapital dan diakhiri dengan tanda titik berupa kalimat berita, tanda tanya berupa kalimat tanya, dan tanda seru berupa kalimat perintah. Jika disampaikan secara lisan ditandai dengan intonasi, tinggi dan rendahnya suara, dan ekspresi (Santosa dan Jaruki 2016:89). Kalimat adalah rangkaian kata-kata yang menunjukan suatu pernyataan atau bahkan berisikan informasi lengkap yang didalamnya terdapat beberapa unsur kalimat berupa subjek $(\mathrm{S})$, prediket $(\mathrm{P})$, objek $(\mathrm{O})$, keterangan $(\mathrm{K})$, dan pelengkap $(\mathrm{P})$. Menulis kalimat terdapat pola dasarnya yaitu pola (1) S-P, (2) S-P-O, (3) SP-Pel, (4) S-P-K, (5) S-P-O-Pel, (6) S-P-O-Pel-K, (7) S-PO-K, dan (8) S-P-Pel-K. Kedelapan pola dasar itu, dapat diturunkan menjadi varian yang tak terbatas sebagaimana dari 26 huruf latin diturunkan menjadi kata tertulis bahasa Indonesia yang tak terbatas (Iswara, 2007).

Menulis kalimat merupakan cara mengajarkan anak untuk dapat menulis yang berisikan informasi lengkap, sehingga nantinya dapat membantu anak dalam proses dikehidupan sehari-hari baik dalam proses belajar bahasa Indonesia, mata pelajaran lain, dan juga meningkatkan kemampuan anak berkomunikasi. Akan tetapi tidak semua anak dapat menulis kalimat dengan baik sehingga menghambat anak dalam proses berkomunikasi, menyampaikan ide dan menghambat proses pembelajaran.

Anak berkesulitan belajar menulis merupakan suatu bentuk kesulitan belajar yang dapat mengakibatkan ketidakseimbangan perkembangan memori dan motorik anak sehingga berpengaruh dalam kemampuan mengungkapkan suatu informasi atau objek kedalam bentuk bahasa tulis (Achrony 2013:35). Sehingga mempengaruhi kemampuan menulis yang diperlihatkan dalam kesulitan mengeja, miskin kosakata, kesulitan menuangkan pemikiran di atas kerta, dan teknik tertentu (Santrock dalam Achrony 2013:35). Salah satu yang menjadi kesulitan menulis untuk anak kelas tinggi yaitu kesulitan menulis ekspresif berupa menuangkan ide dalam bentuk tertulis yang berisikan informasi yang ingin disampaikan.

Dari hasil observasi, wawancara dan asesmen yang dilakukan di SD N 02 Cupak Tangah. Peneliti memperoleh data terdapat anak yang berinisial X memiliki hambatan dalam kegiatan menulis ekspresif terutama dalam menulis kalimat berpola SPOK. Faktor penyebab kesulitan menulis kalimat adalah ketidakmampuan anak dalam pemilihan kata-kata untuk membentuk kalimat yang baik dan kurangnya latihan dalam mengembangkan kemampuan menulis. Dalam kegiatan menulis anak perlu diajarkan menulis berpola dalam membantu memudahkan anak untuk memilih kata-kata dan menambah kosa kata yang dimiliki untuk mengembangkan ide ditulisan sehingga anak mampu menulis kalimat dan dapat mengikuti proses pembelajaran dengan baik.

Beberapa cara telah dilakukan guru untuk mengatasi permasalahan yang dialami anak, seperti melaksanakan latihan-latihan menulis kalimat berdasarkan gambar-gambar yang dilihat atau dengan cara latihan mengarang. Akan tetapi hasil tulisan anak tetap kurang bisa dipahami. Begitu juga kepada guru pembimbing khusus disekolah telah melaksanakan bimbingan tetapi belum melaksanakan bimbingan terhadap kemampuan menulis ekspresif anak, sehingga dalam menulis kalimat belum adanya kemajuan yang baik. Peneliti mengamati anak berinisial X saat proses pembelajaran. Hasil pengataman tersebut peneliti melihat anak dalam proses pembelajaran baik, mengikuti proses pembelajaran sesuai instruksi guru kelas, walau terlihat 
terkadang anak jalan-jalan dalam proses pembelajaran dan kurang bersemagat dalam mengikuti kegitan. Berdasarkan pengamatan peneliti guru dalam proses pembelajaran mengunakan metode ceramah yang diikuti pengunaan media papan tulis, dan buku pembelajaran.

peneliti melaksanakan asesmen lebih lanjut kepada anak X dengan meminta anak untuk membuat 20 kalimat berpola SPOK, dari hasil asesmen yang peneliti berikan anak memperlihatkan hasil yang kurang baik yaitu tidak ada kalimat yang dituliskan dengan benar, anak hanya menuliskan kata-kata saja bukan kalimat yang berisikan kalimat berpola SPOK. Selanjutnya peneliti menguji pengetahuan anak tentang pemahaman unsur-unsur pembentuk kalimat yaitu subjek, predikat, objek, keterangan hasilnya anak tidak juga mengetahui makna pembentuk kalimat tersebut baik itu maknanya ataupun kata yang mengandung subjek, predikat, objek, keterangan. Terlihat dari hasil asesmen anak mengalami kesulitan dalam menulis kalimat berpola SPOK disebabkan ketidaktahuan anak terhadap unsur pembentuk kalimat dan kesulitan dalam pemilihan kata dalam membuat kalimat sehingga membuat anak kesulitan dalam proses belajar mengajar yang berhubungan dengan kegiatan menulis ekspresif.

Dalam membantu anak mengatasi kesulitan menulis dapat dilakukan seperti memberikan latihan menulis secara rutin, libatkan anak secara bertahap, pilih strategi yang sesuai dengan tingkat kesulitannya untuk mengerjakan tugas menulis (Astuti dalam Suharsono, 2016). Anak disgrafia tidak bisa dibiarkan belajar menulis sendiri mereka perlu bimbingan secara khusus (Suharsono, 2016). Penerapan strategi belajar, metode atau pendekatan yang sesuai akan membantu anak dalam menguasai materi yang diajarkan. Salah satu metode yang dapat diterapkan dalam kegiatan menulis kalimat adalah learning contracts method.

Learning contracts method merupakan bentuk metode belajar yang menekankan kepada proses perjanjian antara guru dan anak dengan tujuan tertentu serta dengan pencapaian yang diharapkan bersama-sama. Learning contract adalah salah satu jenis metode di dalam model pembelajaran kooperatif yang dikembangkan guru untuk mengidentifikasi berbagai kebutuhan anak dalam pembelajaran dan aktifitas-aktifitas (Istarani 2011:233). Metode ini berdasarkan kesepakatan bersama disesuaikan dengan materi ajar yang akan diberikan oleh guru dan juga memberikan keleluasaan kepada anak untuk memilih cara belajar yang disukai anak dan nantinya akan tertera terhadap perjanjian belajar.

Learning contracts method dapat diaplikasikan untuk anak berkesulitan belajar, terutama anak berkesulitan belajar menulis kalimat, karena dalam penerapan menulis kalimat diperlukan pemahaman dan keleluasaan menuangkan ide dalam menulis. Learning contracts method diharapkan mampu meningkatkan rasa percaya diri anak untuk menulis dengan diberikan tanggung jawab terhadap kalimat yang akan dikerjakan dan proses belajar disesuaikan dengan kemauan anak dan sekaligus mengidentifikasi kemungkinan kesulitan yang akan dihadapi anak dalam kegiatan menulis kalimat. Sehingga penerapan learning contracts method ini diharapkan akan mampu membantu anak dalam meningkatkan kemampuan menulis kalimat berpola SPOK.Berangkat darimasalah tersebut maka artikel ini akan membahas kemampuan menulis kalimat berpola SPOK melalui learning contracts method untuk anak berkesulitan belajar menulis kelas V di SD N 02 Cupak Tangah.

\section{Metode}

Berdasarkan permasalah yang diteliti yaitu meningkatkan kemampuan menulis kalimat melalui learning contracts method pada anak berkesulitan belajar X, maka peneliti melaksanakan penelitian eksperimen yang berbentuk Single subject Research (SSR). Bentuk Single subject Research (SSR) yang digunakan adalah desain A-B-A. Sunanto (2005:59) menjelaskan bahwa desain A-B-A merupakan pengembangan desain A-B. Desain A-B-A menjelaskan dimana "A1 merupakan kemampuan awal anak atau phase baseline dan B kemampuan setelah diberikan intervensi atau phase intervensi, selanjutnya dilakukan pengukuran baseline kedua setelah tidak lagi diberikan intervensi (A2)".

Variabel dalam penelitian ini ada dua variabel yaitu variabel bebas dan variabel terikat. Variabel terikat yaitu variabel yang timbul akibat adanya variabel bebas. Penelitian ini yang menjadi variabel terikat adalah meningkatkan kemampuan menulis kalimat berpola SPOK dan Variabel bebas adalah variabel yang menyebabkan timbulnya variabel lain. Dalam penelitian ini yang menjadi variabel bebas adalah learning contracts method

Subjek penelitian adalah sesuatu yang dijadikan bahan atau sasaran dalam suatu penelitian. Sunanto (2005:2) menyatakan "Penelitian single subject research (SSR) digunakan untuk subjek tunggal, dalam pelaksanaannya dapat dilakukan pada seorang subjek atau kelompok subjek". Dalam penelitain ini yang menjadi subjek adalah anak berkesulitan belajar berinisial X kelas V di SD N 02 Cupak Tangah. Kondisi fisik anak normal, memiliki anggota tubuh yang lengkap dan berfungsi dengan baik. Namun anak memiliki masalah dalam pembelajaran bahasa Indonesia khususnya pada kegiatan menulis kalimat berpola SPOK yang berhubungan dengan kegiatan menulis ekspresif disebabkan karena anak X kesulitan dalam pemilihan kata dan merangkai kata menjadi kalimat dikarenakan anak tidak paham unsur pembentuk kalimat yang baik sehingga tulisan yang dibuat belum mengandung informasi dan membuat anak mengalami hambatan dalam pembelajaran lainya yang berhubungan dengan kegiatan menulis.

Teknik pengumpulan data dalam penelitian ini adalah observasi dan tes. Dengan alat pengumpul data pada penelitian ini adalah pedoman observasi dan soal tes tertulis. Pedoman observasi bertujuan untuk melihat dan mencatatat kejadian disetiap pertemuan dan pertemuan saat proses belajar mengajar menggunakan learning contacats method dalam menulis kalimat berpola SPOK. Sedangkan pada tes tertulis alat pengumpul datanya berupa soal tes tertulis dengan pengukuran kemampuan menulis kalimat berpola SPOK melalui satuan ukuran frekuensi dengan diberikanya tanda tally kepada setiap susunan kalimat SPOK yang dituliskan dengan benar oleh anak.

Analisis data dalam penelitian ini dengan menggunakan teknik analisis visual grafik, yaitu dengan cara memplotkan data-data kedalam grafik, kemudian data tersebut dianalisis berdasarkan komponen-komponen pada setiap kondisi baseline (A1), intervensi (B), baseline (A2).

\section{Hasil}

Data hasil penelitian Single Subject Research dianalisis dengan menggunakan analisis visual data grafik (Visual Analisis of Grafic Data). Data yang diperoleh dari hasil pengamatan pada kondisi A1 (Baseline sebelum diberikan intervensi), kondisi B (Intervensi), dan pada kondisi A2 (Baseline setelah tidak lagi diberikan Intervensi).

Dalam penelitian ini peneliti melakukan penelitian sebanyak 19 pertemuan dengan rincian lima kali pertemuan untuk kondisi baseline (A1), sedangkan kondisi intervensi (B) dilakukan sebanyak sembilan kali pertemuan, kemudian lima kali pertemuan untuk kondisi baseline (A2). Setiap pertemuan kondisi diukur dengan menghitung frekuensi. Data pada kondisi ini diperoleh melalui pengamatan terhadap baseline (A1) yaitu 12, 12, 12, 12, 12, kondisi intervensi (B) diperoleh data 20, 24, 25, 30, 32, 24, 38, 38, 38 dan pada kondisi baseline (A2) diperoleh data 38, 36, 38, 38, 38.

$\mathrm{Hal}$ ini menunjukkan semakin meningkatnya frekuensi kalimat berpola SPOK yang ditulis dengan benar oleh anak berkesulitan belajar X setelah diberikan perlakuan atau intervensi melalui learning contracts method terlihat dari frekuensi kalimat berpola SPOK yang ditulis dengan benar semakin meningkat pada kondisi intervensi dan pada kondisi baseline A2 juga menunjukan frekuensi kalimat berpola SPOK yang ditulis dengan benar yang meningkat konsisten dengan frekuensi yang tinggi. Lebih jelasnya hasil penelitian dapat dilihat dari grafik dibawah ini : 


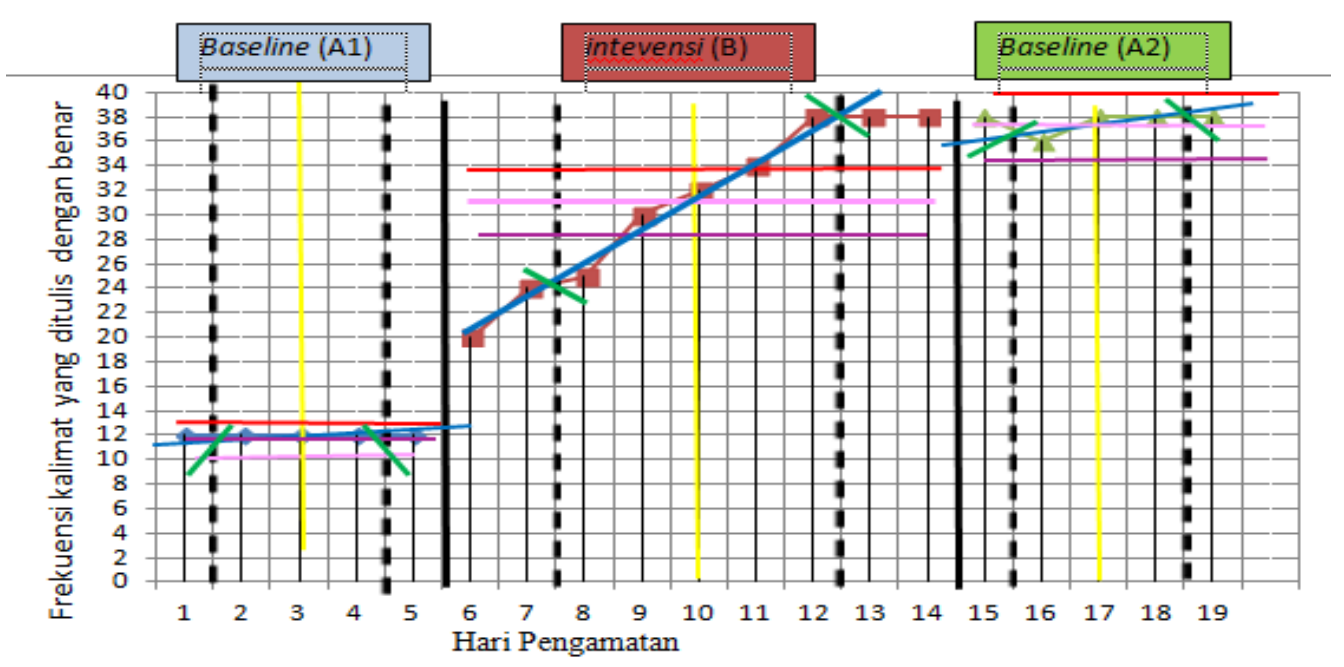

Gambar 1. Frekuensi kalimat yang ditulis dengan benar

Keterangan :

Garis batas kondisi baseline dan intervensi :

Garis Mide Date

Garis Mide Rate

Titik Persimpangan mide date dan mide rate

Garis Kecenderungan Arah

Batas Atas

Batas Bawah

Mean Level

Analisis dalam kondisi pada penelitian ini adalah menganalisis perubahan data yang ada pada grafik dalam masing-masing kondisi. Dari hasil rangkuman analisis visual dapat disimpulkan bahwa kemampuan menulis dapat ditingkatkan melalui learning contracts method. Terlihat dari hasil beberapa komponen pada analisis dalam kondisi yaitu kecendrungan arah frekuensi kalimat berpola SPOK yang ditulis dengan benar anak berkesulitan belajar X pada kondisi baseline (A1) kemampuan tidak mengalami perubahan sebelum diberikan intervensi dengan learning contracts method dengan kecendrungan arah lurus belum adanya perubahan, pada kondisi intervensi (B) kecendrungan arah data pada frekuensi kalimat berpola SPOK yang ditulis dengan benar anak berkesulitan belajar X meningkat yaitu naik dengan keterjalan tinggi setelah diberikan perlakukan ini menunjukan telah adanya perubahan dalam frekuensi kalimat berpola SPOK yang ditulis dengan benar jauh lebih baik, dan pada kondisi baseline (A2) kecendrungan arah meningkat dengan keterjalan rendah ini menunjukan adanya perubahan dalam frekuensi ketepatan dalam menulis kalimat berpola SPOK yang menunjukan kearah yang lebih baik setelah tidak lagi diberikan intervensi.

Dari grafik diatas tergambar jejak data pada kondisi baseline (A1) pada pengamatan pertama sampai pengamatan kelima frekuensi kalimat berpola SPOK yang ditulis dengan benar cendrung mendatar yang menunjukan kemampuan menulis kalimat berpola SPOK yang tidak berubah, sedangkan pada jejak data pada intervensi (B) frekuensi kalimat berpola SPOK yang ditulis dengan benar pada pengamatan keenam sampai empat belas cenderung meningkat dan juga menunjukan jejak data dengan keterjalan tinggi yang berarti frekuensi kalimat berpola SPOK yang ditulis dengan benar adanya perubahan yang signifikan kearah positif yang berarti kemampuan menulis kalimat berpola SPOK meningkat, dan jejak data pada kondisi baseline (A2) pada pertemuan ke lima belas sampai kesembilan belas kecendrungan jejak data meningkat dengan keterjalan rendah yang menunjukan adanya perubahan frekuensi kalimat berpola SPOK yang ditulis dengan benar kearah yang positif yang berarti kemampuan menulis kalimat berpola SPOK yang ditulis anak meningkat dengan data yang tidak jauh berubah.

Dari grafik di atas dapat dijelaskan bahwa hasil persentase stabilitas frekuensi kalimat berpola SPOK yang ditulis dengan benar pada kondisi sebelum diberikan intervensi (A1) mendapatkan persentase stabilitas $100 \%$ yang menunjukan persentase stabil yang berarti data frekuensi kalimat berpola SPOK yang ditulis dengan benar yang didapat dari tiap pertemuan cendrung sama, kondisi intervensi (B) mengalami persentase stabilitas yang tidak stabil yaitu 22.22\% yang berarti data frekuensi kalimat berpola SPOK yang ditulis dengan benar yang didapat cendrung beragam, dan persentase stabilitas setelah tidak diberikan perlakukan (A2) menunjukan angka yang stabil yaitu 100\% yang berarti data frekuensi kalimat berpola SPOK yang ditulis dengan benar pada kondisi ini cendrung sama. Persentase stabilitas dapat dikatakan stabil apabila persentasenya mencapai angka 85\%-95\%. Adapun rangkuman komponen dalam analisis dalam kondisi sebagai berikut : 
Tabel 1. Rangkuman Analisis Data Dalam Kondisi

\begin{tabular}{|c|c|c|c|}
\hline Kondisi & A1 & $\mathbf{B}$ & A2 \\
\hline Panjang Kondisi & 5 & 9 & 5 \\
\hline \multicolumn{4}{|l|}{ Estimasi kecenderungan arah } \\
\hline & $(=)$ & $(+)$ & $(+)$ \\
\hline Kecenderungan Stabilitas data & $\begin{array}{l}100 \% \\
\text { (stabil) }\end{array}$ & $\begin{array}{c}22,22 \% \\
\text { (tidak stabil) }\end{array}$ & $\begin{array}{c}100 \% \\
\text { (stabil) }\end{array}$ \\
\hline \multicolumn{4}{|l|}{ Kecenderungan Jejak Data } \\
\hline & $(=)$ & $(+)$ & $(+)$ \\
\hline Level Stabilitas dan Rentang & $\begin{array}{c}\text { Stabil } \\
(12-12)\end{array}$ & $\begin{array}{l}\text { Variabel } \\
(20-38)\end{array}$ & $\begin{array}{c}\text { Stabil } \\
(38-38)\end{array}$ \\
\hline Level perubahan & $\begin{array}{c}12-12=0 \\
(=)\end{array}$ & $\begin{array}{c}38-20=8 \\
(+)\end{array}$ & $\begin{array}{c}38-36=2 \\
(+)\end{array}$ \\
\hline
\end{tabular}

Selain komponen dalam kondisi ada komponen-komponen dalam analisis antar kondisi dapat dibuktikan bahwa hasil yang diperoleh cenderung stabil dari grafik antar kondisi, hasil yang didapat adalah pada perubahan kecendrungan arah dan efek menunjukan kondisi baseline (A1) kecendrungan arah mendatar yang menunjukan bahwa tidak adanya perubahan frekuensi kalimat berpola SPOK yang ditulis dengan benar yang berarti kemampuan dalam menulis kalimat berpola SPOK tidak ada perubahan, sedangkan pada intervensi (B) terlihat kecendrungan arah naik dengan keterjalan yang tinggi yang berarti adanya perubahan kecendrungan arah kearah posif yang menunjukan adanya perubahan frekuensi kalimat berpola SPOK yang ditulis dengan benar yang artinya adanya perubahan kemampuan menulis kalimat berpola SPOK saat diberikan intervensi, dan pada baseline (A2) menunjukan adanya perubahan frekuensi menulis kalimat berpola SPOK kearah positif dengan kecendrungan arah meningkat dengan keterjalan rendah yang menunjukan adanya peningkatan kemampuan menulis kalimat berpola SPOK setelah diberikanya intervensi.

Menentukannya dengan melihat kecenderungan stabilitas pada kondisi A1, B, A2 pada rangkuman analisis dalam kondisi. Dapat dikatakan bahwa pada kondisi baseline (A1) frekuensi kalimat berpola SPOK yang ditulis dengan benar berkisar 12-12, ini menunjukan adanya frekuensi yang stabil dan menunjukan kemampuan anak dalam menulis kalimat berpola SPOK yang tidak terlalu baik dengan data yang konsisten. Sedangkan kondisi intervensi (B) setelah diberi intervensi mengalami perubahan frekuensi kalimat berpola SPOK yang ditulis oleh anak X dengan data sekitar 20-38, ini menunjukan adanya perubahan frekuensi yang cukup signifikan dari kondisi baseline A1 yang menunjukan adanya pengaruh pemberian intervensi berupa penerapan learning contracts method terhadap frekuensi kalimat berpola SPOK yang ditulis dengan benar dan juga didukung dengan frekuensi yang semakin meningkat pada kondisi intervensi yang artinya adanya perubahan kemampuan menulis kalimat berpola SPOK kearah yang lebih baik, dan kondisi baseline tanpa perlakuan (A2) menunjukan frekuensi kalimat berpola SPOK yang ditulis dengan benar oleh anak berkesulitan belajar X yaitu berkisar antara 36-38 yang menunjukan frekuensi kalimat berpola SPOK yang ditulis dengan benar tidak jauh berbeda dari pada kondisi intervensi yang dapat diartikan adanya perubahan kemampuan menulis kalimat berpola SPOK kearah yang lebih baik.

Hasil perhitungan overlap data pada kondisi baseline sebelum diberikan intervensi (A1) dan intervensi (B) adalah $0 \%$ yang berarti pemberian intervensi terhadap kemampuan menulis kalimat berpola SPOK melalui learning contracs method memberikan pengaruh yang baik ditunjukan dengan perolehan overlape $0 \%$ yang mana semakin kecil overlape yang didapat maka semakin baik pula pengaruh intervensi terhadap target behavior, dengan demikian dapat diartikan frekuensi kemampuan menulis kalimat berpola SPOK meningkat setelah diberikanya intervensi yang menunjukan kemampuan menulis kalimat berpola SPOK anak berkesulitan belajar X yang semakin meningkat. Perhitungan overlap data pada kondisi baseline setelah tidak lagi diberikan intervensi, baseline (A2) dan intervensi (B) mendapatkan hasil 33,33\% ini menunjukan data yang lebih besar dari pada overlape baseline (A1) dan intervensi (B) tetapi masih pada overlap yang relatif kecil, ini menunjukan pengaruh intervensi terhadap targer behavior adalah baik, yaitu ditandai dengan meningkatnya frekuensi kalimat berpola SPOK yang ditulis dengan benar oleh anak berkesulitan belajar X meningkat setelah tidak lagi diberikan intervensi, yang artinya adanya peningkatnya kemampuan menulis kalimat berpola SPOK anak berkesulitan belajar. Rangkuman data komponen dalam kondisi dapat kita lihat dari tabel sebagai berikut : 
Tabel 2. Rangkuman Analisis Dara Antar Kondisi

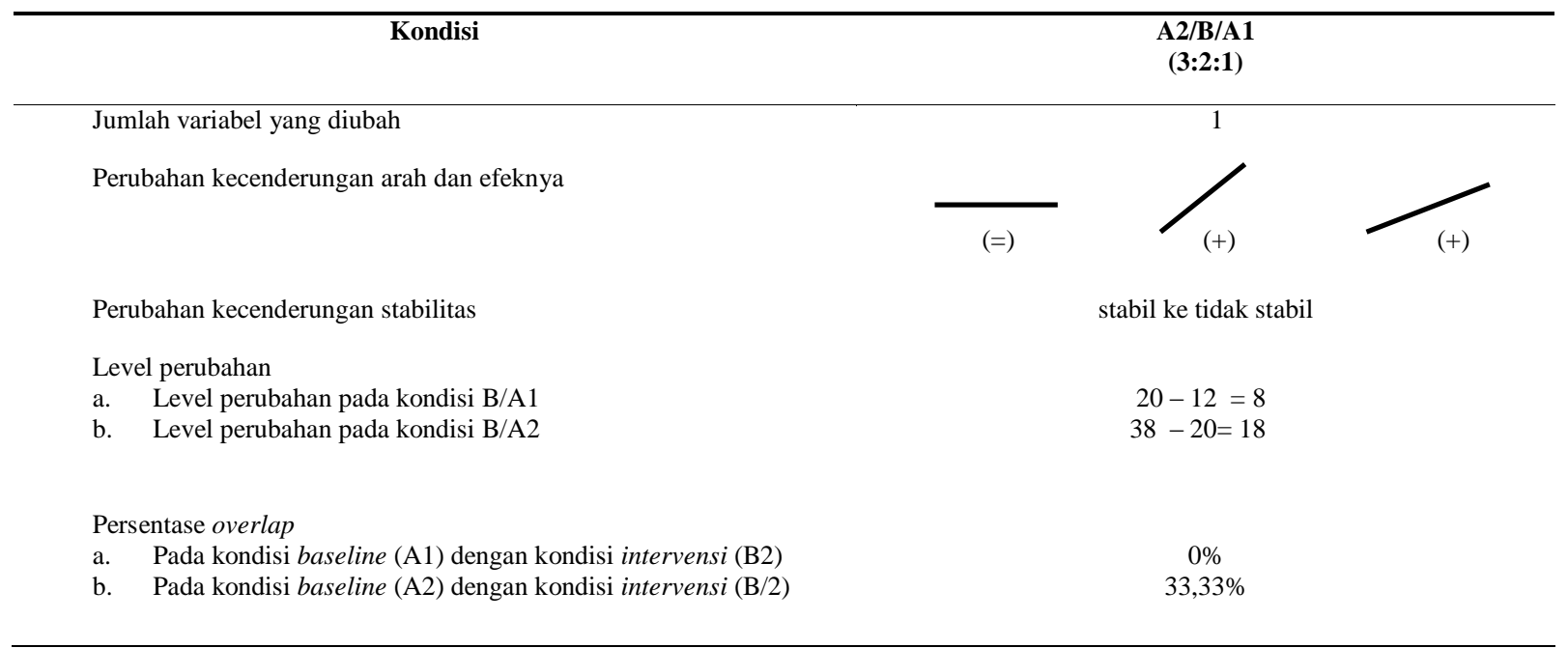

\section{Diskusi}

Anak berkesulitan belajar menulis yaitu anak yang memiliki hambatan dalam proses tahapan menulis baik dalam menulis permulaan ataupun menulis lanjutan yang ditandainya ketidakjelasan tulisan, tulisan jelek, tidak inginya menulis dan tulisan yang tidak mampu dipahami maknanya, faktor yang menyebabkan kesulitan menulis dapat dari anak atau dari luar seperti kurangnya kesempatan atau metode belajar yang kurang sesuai. Menurut Menurut Jordon (dalam Abdurrahman 2010:181) disgrafia adalah "ketidakmampuan seseorang untuk mengingat cara membuat huruf atau simbol matematika." dan Santrock (dalam Achrony 2013:35) mengemukakan kesulitan belajar menulis atau disgrafia merupakan "ketidakmampuan dalam belajar yang mempengaruhi kemampuan menulis yang diperlihatkan dalam kesulitan mengeja, miskin kosakata, kesulitan menuangkan pemikiran di atas kerta, dan teknik tertentu".

Intervensi yang diberikan pada anak berkesulitan belajar menulis X menggunakan learning contracts method mampu meningkatkan keinginan anak dalam belajar menulis kalimat berpola SPOK. Terlihat saat proses belajar mengajar anak memiliki keinginan tersendiri dalam belajar, sehingga dalam proses belajar tumbuh rasa percaya diri dan bertanggung jawab terhadap tugas yang dikerjakan sehingga membuat hasil belajar anak semakin baik. Anak yang memiliki kepercayaan diri yang baik akan mendapatkan hasil belajar yang baik, sebaliknya anak yang kurang percaya diri kurang berani menghadapi tantangan, tidak percaya akan kemampuan akan mendapatkan hasil belajar yang kurang baik (Agustyaningrum \& Suryantini, 2015).

Kegiatan dalam pelaksanaan menulis kalimat melalui learning contracts method yaitu peneliti melihat kesiapan anak terlebih dahulu, setelah siap untuk belajar peneliti membimbing anak untuk berdoa, selanjutnya peneliti saat pertemuan pertama intervensi melaksanakan kontrak belajar bersama anak yang isi kontrak belajar adalah topik pembelajaran, tujuan belajar, stategi belajar dan penyerahan tugas. Kegiatan intervensi dilaksanakan berdasarkan kontrak belajar yang telah ditandatanggani oleh anak dan peneliti untuk dilaksanakan. Anak dalam kontrak belajar memilih stategi belajar dengan memberikan penjelasan langsung oleh peneliti dengan tanggung jawab penuh terhadap tugas yang diberikan. Saat intervensi anak diminta membuat kalimat berdasarkan tema yang disepakati, kemudian anak diminta mengerjakan tugas secara independen dan peneliti disini menjadi pendamping dan akan siap menjelaskan kepada anak saat anak mengalami kesulitan dalam pengerjaan soal. Kemudian diakhir pengerjaan tugas peneliti menanyakan kembali kesulitan anak dalam pengerjaan tugas dan menjelaskan kepada anak, dan berdasarkan perjanjian tugas dikembalikan saat pelaksanaan intervensi. Pelaksanaan pembelajaran menggunakan learning contracts memiliki kelebihan diantaranya, (1) meningkatkan kemandirian anak dalam proses belajar mengajar, (2) menigkatkan tanggung jawab siswa, (3) Memberikan keleluasaan kepada anak untuk mencari tambahan bahan dan tinjauan pembelajaran, (4) Melatih anak bagaimana membuat kontrak atau bekerjasama dengan orang lain (Istarani, 2013:123).

Tiga fase penelitian menunjukan, fase baseline (A1) sebelum diberikan intervensi dengan learning contracts method dengan hasil anak belum mampu menulis kalimat berpola SPOK, pedengan data stabil, selanjutnya fase intervensi (B) yaitu memberikan perlakukan terlihat kemampuan menulis kalimat berpola SPOK semakin meningkat dengan keterjalan tinggi, dan fase terakhir fase baseline (A2) setelah diberikan intervensi dilaksanakan kemampuan menulis kalimat berpola SPOK anak meningkat stabil.

Pemaparan diatas dibuktikan dari data kemampuan sebelum diberikan perlakukan melalui learning contracts method frekuensi kalimat berpola SPOK yang ditulis dengan benar oleh anak berkesulitan belajar X rendah dengan rentang nilai (12-12). Tetapi setelah diberikan perlakukan dengan learning contrasts method, frekuensi kalimat berpola SPOK yang ditulis dengan benar oleh anak berkesulitan belajar X lebih meningkat dengan rentang nilai (20-38) dan setelah perlakukan dengan menggunakan learning contracts method dihentikan, frekuensi kalimat berpola SPOK yang ditulis dengan benar meningkat dengan rentang nilai (38-38). Analisi data menunjukan bahwa kemampuan menulis kalimat berpola SPOK semakin meningkat.

Hal ini menunjukkan bahwah kemampuan menulis kalimat berpola SPOK anak berkesulitan belajar X kelas V di SD N 02 Cupak tangah meningkat setelah diberikan intervensi melalui learning contracts method. sesuai pendapat Istarani (2013:123) yang menyatakan penerapan learning contracts method mampu melatih anak untuk menulis, mengarang dan menuangkan hasil bacaan, pikiran, ide dan gagasannya dalam sebuah laporan yang dapat dipertanggung jawabkan.

Hasil penelitian ini sesuai dengan penelitian terdahulu oleh Nur Mustaqim (2014) yaitu meningkatkan keaktifan belajar matematika dengan learning contracts method kelas V MI Magelang. Hasilnya menunjukan bahwa penerapan learning contracts method mampu meningkatkan keaktifan belajar matematika siswa kelas V MI Magelang. Lebih lanjutnya penelitian Erica Adi Purwalaga (2015) mendapatkan hasil bahwa penerapan learning contracts method mampu meningkatkan minat belajar siswa tema indahnya negeriku pada kelas IV SD N 2 Jatinon Surakarta.

\section{Kesimpulan}

Kegiatan intervensi menggunakan learning contracts method mampu membuat proses belajar mengajar lebih baik terutama dalam proses belajar mengajar menulis kalimat berpola SPOK. Learning contracts method membuat anak memiliki tantangan sendiri dalam belajar sehingga meningkatnya motivasi dan rasa percaya diri anak dalam belajar menulis kalimat berpola SPOK dikarenakan adanya tanggung jawab penuh terhadap tugas menulis kalimat berpola SPOK yang diberikan melalui kontrak belajar. 
Perkembagan kemampuan menulis kalimat berpola SPOK dapat dilihat dari pengamatan yang dilakukan berupa pengamatan kondisi baseline (A1) yang merupakan pengamatan yang dilakukan untuk melihat kemampuan awal anak dan terlihat kemampuan menulis kalimat berpola SPOK cukup rendah. Pada kondisi baseline (B) anak diberikan perlakukan dengan menggunakan learning contracts method dan saat diberikan perlakuan kemampuan menulis kalimat berpola SPOK meningkat. Kemudian pengamatan selanjutnya, yaitu kondisi baseline (A2), yaitu kondisi dimana tidak lagi diberikan perlakukan dan pada pengamatan ini mendapatkan dengan hasil kemampuan menulis kalimat berpola SPOK meningkat.

Berdasarkan analisis data dalam kondisi dan antar kondisi. Hasil estimasi kecendrungan arah, kecendrungan stabilitas, jejak data dan perubahan level yang menunjukan data yang positif yang menunjukan kemampuan menulis kalimat berpola SPOK yang meningkat. Hasil perolehan data ini menunjukan bahwa learning contracts method efektif dalam meningkatkan kemampuan menulis kalimat berpola SPOK anak berkesulitan belajar kelas V SD N 02 Cupak Tangah.

\section{Daftar Rujukan}

Abdurrahman, Mulyono. (2010). Pendidikan Bagi Anak Kesulitan Belajar. Jakarta : Rineka Cipta.

Achrony, Keen. (2013). Strategi Pembelajaran Untuk Anak Disgrafis.Yogyakarta. Grup Relasi Inti Media.

Agustyaningrum, Nina \& Suryantini, Silfia. (2015). Hubungan Kebiasaan Belajar Dan kepercayaan Diri Dengan Hasil Belajar Matematika Siswa kelas VIII SMP N 27 Batam. Jurnal Imiah Pendidikan Matematika. 1 (2). 6-7.

Febriana, Nurul Fitri. (2015). Pendekatan Saintifik Terhadap Menulis Deskripsi Anak Kesulitan Menulis (Disgrafia) Kelas IV. Jurnal Pendidikan Khusus. $2-6$.

Istarani. (2011). 58 Model Pembelajaran Inovatif. Medan : Media Persada.

Iswara, Prada D. (2007). Pembelajaran Kalimat Bahasa Indonesia dengan Pola Spiral pada Program Pendidikan Guru Sekolah Dasar. Jurnal Pendidikan Dasar, (8). 3.

Santosa, Puji dan Mohammad Jaruki. (2016). Mahir Berbahasa Indonesia baik, benar dan santun. Bandung : PT Remaja Risdakarya.

Suharsono. (2016). Pembelajaran Menulis Untuk Anak Disgrafia di Sekolah Dasar. Jurnal Transvormatika, 12 (1). 8.

Sunanto, Juang. (2005).Pengantar Penelitian dengan Subjek Tunggal. University Of Tsukuba.

Latae, Azlia., Barasandji. S., \& Muhsin. (2015). Upaya Meningkatkan Kemampuan Menulis Permulaan Siswa Melalui Metode SAS Siswa Kelas 1 SDN Tondo Kecamatan Bungku Barat Kabupaten Morowali. Jurnal Kreatif Tadulako Online. 2 (4). 3-4 